\title{
Spousal rape: A challenge for pastoral counsellors
}

\begin{tabular}{|c|c|}
\hline \multicolumn{2}{|c|}{$\begin{array}{l}\text { Authors: } \\
\text { James A. Glanville }{ }^{1} \\
\text { Yolanda Dreyer }^{1}\end{array}$} \\
\hline \multicolumn{2}{|c|}{$\begin{array}{l}\text { Affiliations: } \\
{ }^{1} \text { Department of Practical } \\
\text { Theology, University of } \\
\text { Pretoria, South Africa }\end{array}$} \\
\hline \multicolumn{2}{|c|}{$\begin{array}{l}\text { Note: } \\
\text { This article represents a } \\
\text { reworked version of aspects } \\
\text { from the PhD dissertation } \\
\text { (University of Pretoria, April } \\
2013 \text { ), entitled 'Spousal rape: } \\
\text { An integrative approach to } \\
\text { pastoral counselling', with } \\
\text { Prof. Dr Yolanda Dreyer as } \\
\text { supervisor. }\end{array}$} \\
\hline \multicolumn{2}{|c|}{$\begin{array}{l}\text { Correspondence to: } \\
\text { James Glanville }\end{array}$} \\
\hline \multicolumn{2}{|c|}{$\begin{array}{l}\text { Email: } \\
\text { info@crisissupportservices. } \\
\text { org }\end{array}$} \\
\hline \multicolumn{2}{|c|}{$\begin{array}{l}\text { Postal address: } \\
\text { PO Box 363, Pinegowrie } \\
\text { 2123, South Africa }\end{array}$} \\
\hline \multicolumn{2}{|c|}{$\begin{array}{l}\text { Dates: } \\
\text { Received: } 04 \text { Feb. } 2013 \\
\text { Accepted: } 12 \text { Apr. } 2013 \\
\text { Published: } 21 \text { June } 2013\end{array}$} \\
\hline \multicolumn{2}{|c|}{$\begin{array}{l}\text { How to cite this article: } \\
\text { Glanville, J.A. \& Dreyer, } \\
\text { Y., 2013, 'Spousal rape: } \\
\text { A challenge for pastoral } \\
\text { counsellors', HTS Teologiese } \\
\text { Studies/Theological Studies } \\
\text { 69(1), Art. \#1935, } 12 \text { pages. } \\
\text { http://dx.doi.org/10.4102/ } \\
\text { hts.v69i1.1935 }\end{array}$} \\
\hline \multicolumn{2}{|c|}{$\begin{array}{l}\text { Copyright: } \\
\text { (C) 2013. The Authors. } \\
\text { Licensee: AOSIS } \\
\text { OpenJournals. This wo } \\
\text { is licensed under the } \\
\text { Creative Commons } \\
\text { Attribution License. }\end{array}$} \\
\hline \multicolumn{2}{|l|}{ Read online: } \\
\hline 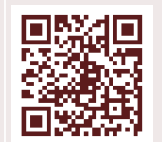 & $\begin{array}{l}\text { Scan this QR } \\
\text { code with your } \\
\text { smart phone or } \\
\text { mobile device } \\
\text { to read online. }\end{array}$ \\
\hline
\end{tabular}

This article reflects on the criticism regarding the pastoral counsellor's dealings with spousal rape victims. It argues that counsellors should be sensitive not to be biased, either personally or theologically, and should have an understanding of the biopsychosocial (biological, psychological and social) impact of spousal rape, such as rape-related post-traumatic stress and other related illnesses such as depression, victimisation and stigmatisation. The pastoral counsellors should be aware of the legal and medical ramifications of spousal rape and have knowledge of the correct referral resources and procedures (trusted professionals, shelters and support structures). They should be self-aware and understand the effect that gender or previous traumatic personal experiences may have on their reactions. The article consists of the following sections: the phenomenon 'rape'; acquaintance rape; spousal rape; post-traumatic stress; post-traumatic stress disorder; rape trauma syndrome; cognitive behavioural therapy; spirituality; doctrinal matters; social system of patriarchy; a pastoral counselling model; self-care.

\section{Introduction}

Recent crime statistics indicate that there is still a high incidence of rape reported in South Africa. The latest statistics (April 2011 - March 2012) from the South African Police Services (2012:1) indicate that 64514 cases of sexual assault were reported during this time period. The present lack of supportive rape intervention resources and services in South Africa is likely to exacerbate the post-traumatic stress women experience due to rape.

Any aid to the well-being of spousal rape victims is multifaceted and involves aspects such as individual care and therapy; community involvement; mentorship programmes; gender related issues and the integration and application of theological perspectives. Furthermore, the interpersonal characteristics and dynamics of the individuals involved in the healing of the spousal rape victims are significant. The greatest asset to pastoral counselling is therefore the person of the pastoral counsellor. Tan (2011:16) characterises four distinctives of pastoral counsellors: they have unique assumptions which are based on biblical principles and teaching; they have unique goals, not only to alleviate psychological suffering but also to facilitate spiritual growth; they have unique methods which may differ from standard counselling methods and techniques and which add the use of scripture and prayer; they have a unique giftedness, are called by God and equipped by God's Spirit. It then follows that pastoral counsellors have a unique role to play in the well-being of the victim of spousal rape.

\section{The pastoral counsellor and criticism}

There has been much criticism regarding the pastoral counsellor's dealings with spousal rape victims for good reason. They are not always considered to be a viable resource for such individuals. A South African study (Rasool et al. 2003:102) revealed that whilst a number of women felt that the church played a positive role in their lives, they did not feel the church was effective in dealing with issues of violence against women. According to West (2004:42), pastoral counsellors sometimes perpetuate cultural attitudes that encourage shame and silence regarding rape. Smith (1998:341) applies this finding specifically to evangelicals: 'Because evangelicals often see themselves as more righteous than non-Christians, they often discourage victims from seeking help in secular agencies should the church prove incapable of handling the assault.' Whilst clergy often think that only they should help, they tend to experience a degree of anxiety when doing so (see Nason-Clark 1997:64). Further, it would seem that not all assistance offered by pastoral counsellors is useful. Delaphane and Delaphane (2004:158) put it as follows: 'Probably the most damaging pastoral response to a victim of rape is that of judgementalism or questioning as to what she did to invite the act.' Scholtz (2004:209) concurs and points out that, rape victims rarely have the support of religious leaders and thinkers. Andersen's (2007:71) assessment of the aforementioned approach is that it perpetuates the problem, 'amounting to nothing less 
than church-sanctioned oppression.' Bergen (1996:52) indicates that support for women in violent relationships is not always forthcoming from pastoral counsellors. In some cases, the advice given to a victim is to 'obey your husband' and not refuse him sexual intercourse. This merely serves to exacerbate the problem of spousal rape.

In my own research, victims of spousal rape had negative perceptions of pastoral counsellors. Those who had been counselled by pastoral counsellors reported that they received little assistance.

This does not suggest that pastoral counsellors have no role to play in the healing of spousal rape victims. Rather, pastoral counsellors should ideally have a vital role to play in their healing process. In order to be effective however, certain guidelines need to be adhered to. Pastoral counsellors should have a thorough knowledge of the dynamics of rape in general and spousal rape in particular. They should not be biased, either personally or theologically and should have an understanding of the biopsychosocial (biological, psychological and social) impact of spousal rape, such as rape-related post-traumatic stress or other related illnesses such as depression, victimisation and stigmatisation. Pastoral counsellors should be aware of the legal and medical ramifications of spousal rape and have knowledge of the correct referral resources and procedures (trusted professionals, shelters and support structures). They should be self-aware and understand the effect that gender or previous traumatic personal experiences may have on their reactions and interactions with rape victims.

\section{The pastoral counsellor and rape}

Whilst rape is not an unknown phenomenon, there are possible misunderstandings as to what exactly constitutes rape. A possible reason for this is that the definition of rape has changed over the years. Purdy (2004:122) believes that rape 'was used to define the act wherein one man damaged the property of another.' This definition is neither useful nor adequate, as it violates the rights and personhood of women. A number of different factors may contribute to the confusion of defining rape in appropriate terms; the relationship between rape victim and perpetrator; the circumstances in which the rape occurred; whether or not a woman is considered to be compliant and the age of the rape victim.

A general understanding of rape today is that it is considered to be a forceful and violent act, committed mainly by individuals who are unknown to the victim, who have no other agenda than to assert their authority and dominate and control women (see Tasman \& Mohr 2011:409; Van Niekerk 2006:1). This study considers the previous definitions to be lacking and holds to the definition of the Criminal Law (Sexual Offences and Related Matters) Amendment Act, 2007: 'Any person (A) who unlawfully and intentionally commits an act of sexual penetration with a complainant (B), without the consent of B, is guilty of the offence of rape' (South Africa Government 2007:20). This definition takes into consideration that rape is unlawful, due to the fact that it involves a lack of sexual consent. It also recognises that rape can transcend age, class, social or gender boundaries. It views rape as an intended act committed by a perpetrator and/or perpetrators. Secondly, rape may or may not consist of force and/or violence. Thirdly, consent is considered to have been denied if the victim was mentally impaired. This could have been due to the use of medication, intoxication, mental retardation or fear and intimidation. Finally, rape may occur between partners who are married to each other, or between acquaintances and strangers.

Apart for the various ways in which rape may be defined, there are also a number of theories with regard to rape (see Ellis 1989; Burgess-Jackson 1996). Whilst there is not one theory which definitively explains the phenomenon rape, each theory adds value to the explanation of why rape is perpetrated by men against women. This study associates itself with the Social Learning Theory in particular and proposes that men act out violence and rape women because they have learnt this through exposure to other men who have abused women and also to a generally disrespectful and derogatory view of women. This could be due to their own individual childhood experiences or due to exposure to bad social practices where women have been viewed as being the property of men. According to Wiehe and Richards (1995:71), children exposed to emotional trauma often learn patterns of violence, including sexual violence and then duplicate this violence whilst they are still young and into their adult lives.

Myths regarding rape are also a factor with regard to the understanding of this phenomenon. Whether these myths are held by the victims, perpetrators or society, they are damaging to both victims and society in general and cause confusion, blame and guilt. A clear understanding of the nature and dynamics of rape is therefore necessary in order to appropriately address this phenomenon.

Certain factors complicate the phenomenon of rape, one such factor being that of the legal system. This includes the victim's interaction with the police, prosecutors, as well as the dynamics of the trial. The judgement pronounced at the rape trial also significantly influences the future well-being of the rape victim. The legal system may in fact cause the rape victim to undergo a form of secondary traumatisation. This study uses the term 'secondary traumatisation', to refer to any ongoing trauma due to the victim's interaction with those involved in the initial traumatic event (viz. the perpetrator or perpetrators) and with additional persons and institutions (such as the legal system).

The justice system places a legal burden on women to demonstrate the lack of consent to sexual intercourse, or it is de facto assumed that they have in fact consented. McGregor (2005:105) therefore poses the question: 'Is consent a useful concept, one that helps distinguishes lawful from unlawful conduct?' 
If consent is then a vital factor with regard to rape, the question of what constitutes consent needs to be addressed. Consent is to be understood as permission being expressed either by attitude or other means of other verbal or nonverbal communication. Consent must also be distinguished from an undirected action (i.e. action that is not made with intent). Importantly, consent is not simply the absence of refusal or resistance and can be withdrawn at any time.

In light of the aforementioned (amongst others not addressed in this article), it is not surprising that many women who have been raped choose not to lay charges against their perpetrators. Smythe and Waterhouse (2008:200) refer to the 2005 National Youth Victimisation Study (see Leoschut \& Burton 2006) and draw attention to the fact that of the $83.2 \%$ sexual assault victims who shared their experience with someone, only $11.3 \%$ reported the assault to the police.

Every rape victim has the possibility of suffering long-term negative physical, psychological, social and spiritual side effects. Rape victims are predisposed to suicide attempts, clinical depression, panic, anxiety, phobias and traumatic stress symptoms (Bachar \& Koss 2002:898). According to Astbury (2006):

Of all the traumatic stressors researched so far, including natural disasters such as earthquakes, hurricanes and tsunamis, it is the 'man-made' trauma of sexual violence that most strongly predicts the subsequent development of post-traumatic stress disorder (PTSD). (p. 5)

Astbury (2006:5) also believes that rape victims constitute the single largest group suffering from post-traumatic stress disorder. This fact is reinforced by Vetten (2007:23), who notes that rape victims are six times more likely to develop post-traumatic stress disorder (PTSD) at some or other point in their lives.

\section{Acquaintance rape}

According to Wiehe and Richards (1995:10-14), the majority of rapes $(50 \%-85 \%)$ are carried out by a known acquaintance and in a familiar residence (61\%). Further, victims of acquaintance rape are less likely to seek support from friends, family, crisis centres and the police than those who are victims of a stranger rape. The complications of acquaintance rape are compounded if a rapist interacts within the victim's immediate social circle. There are heightened feelings of fear, guilt, anger, frustration, shame and self-blame for the victim of acquaintance rape (see Easteal 1998:18; Leslie 2003:6). The extent of psychological injury may be greater than that of stranger-raped victims, who may be safer to openly discuss their ordeal with others, thereby releasing pent-up emotions. Finally, it appears easier for the court to acknowledge stranger rape than acquaintance rape (see Leslie 2003:5), which results in acquaintance rape having a lower conviction rate than stranger rape.

\section{Spousal rape}

Spousal rape differs from acquaintance rape in that the victim not only knows the perpetrator but the spousal perpetrator is meant to be regarded as her life partner. This severely affects the spousal rape victim's ability to trust, et cetera.

Spousal rape is considered to be a foreign concept in the scriptures. One of the reasons suggested for this, is that the wife is recognised as being the property of the husband and as such, has no authority to deny sexual intercourse with her husband. Emmerson (1995:382) indicates that this is not in accordance with the teachings of God in the Old Testament (see Goldingay 2009:355). Nevertheless there is much narrative in the Old Testament that demonstrates that husbands abused their God-given responsibilities and treated their wives as possessions (see Gn 12:14-19). Patriarchy is further promoted in the New Testament however, husbands have again misappropriated the system and have abused their wives. This concept of biblical patriarchy is discussed below.

According to Naylor (2008:26), the marital rape exemption has been abolished in South Africa in 1993 under the Prevention of Family Violence Act. It was therefore not until recently that it was possible for a man in South Africa to be charged with the rape of his wife. The occurrence of spousal rape has been perceived to be low, yet the Centre for the Study of Violence \& Reconciliation (CSVR) (2001:4) reports:

National statistics supplied by the South African Police Services (SAPS) National Crime Information Centre indicate that approximately $1 \%$ of rapes reported during 1996 and 1997 were perpetrated by husbands upon wives. (p. 4)

This may be considered to be a low percentage however spousal rape is also the least likely category of rape to be reported to the police (Tjaden \& Thoennes 2000:49).

Bergen (2006:6) found that some spousal rape victims do not consider their experiences as being rape, due to the common perception that only stranger rape is 'real rape' and that sex in marriage is culturally considered obligatory. This implies that spousal rape does not only take place within a radical breakdown of the marriage relationship itself, but that it is also often linked to other forms of domestic violence. Pastoral counsellors should therefore not consider spousal rape as merely another manifestation of domestic violence. This is not always the case.

The Development Research Africa and CSIR Defence, Peace, Safety and Security Unit (2008) finds that:

there is a high level of awareness of the criminality of domestic violence among respondents in this study - with $92 \%$ believing that what had been done to them was a crime. However, very few respondents understood that forced sex within a relationship or with someone known to them respondent is rape. (p. 73)

Gelles (1997:77) points out that between $10 \%$ and $14 \%$ of married women have experienced rape in marriage. Randall and Haskell (1995; cf. Bergen 2006:1) found that 30\% of women, who were sexually assaulted as adults, were actually sexually assaulted by their intimate partners. Further, Mahoney and Williams (2007:7) estimate that 'one in ten to one in seven married women will experience a rape by a husband.' 
An additional issue regarding victims of spousal rape, according to Kernsmith (2008:58), is that $70 \%$ to $85 \%$ of spousal rape victims experience more than one rape and $30 \%$ to $55 \%$ report in excess of 20 incidences (see Greenberg, Bruess \& Conklin 2010:540). Spousal rape frequently involves intense physical and psychological injury. According to Mahoney \& Williams (2007:3), 'many victims of wife rape also suffer severe physical injuries and endure multiple rapes throughout their marriages.' Whilst spousal rape victims also suffer other forms of domestic violence, spousal rape must be addressed as a distinctive issue and not merely an extension of domestic violence as a whole.

Spousal rape has severe and prolonged psychological traumatic consequences for wives, including the development of post-traumatic stress disorder (Weaver et al. 2007:478). According to Plichta and Falik (2001:251), victims of spousal rape are more often diagnosed with depression or anxiety than are victims of physical violence or sexual abuse either by strangers or acquaintances.

For spousal rape victims, seeking help is frequently a complicated process. Mahoney and Williams (1998:9) report that women raped by a partner are often reluctant to report the assault and are less likely to seek medical or psychological assistance than those who have been assaulted by strangers or acquaintances.

\section{The pastoral counsellor and post- traumatic stress}

In order to effectively counsel the victim of a traumatic event such as rape, pastoral counsellors should have an adequate understanding of the psychological trauma and a grasp of the enormity of the event for the victim.

According to Weaver et al. (2004), the word trauma:

is derived from the Greek word meaning 'wound'. Just as a physical trauma can cause suffering by wounding and disabling the body, a psychological trauma can cause suffering by overwhelming the thoughts and feelings. (p. 9)

Unlike many psychological issues, traumatic stress is linked to an event and the individual's unique reaction to that event. Trauma intervention then focuses not only on the victim's current reactions, but also the victim's experience of the event (or the factual happening, thoughts and emotions that took place during the traumatic event).

According to the Diagnostic and Statistical Manual of Mental Disorders (DSM-IV), the psychological definition of traumatic stress is a 'traumatic event' in which the person faced an event that threatened serious injury or death; or a threat to the physical integrity of self or others, thereby resulting in feelings of fear, helplessness, or horror (American Psychiatric Association 1994:427-428). Weaver et al. (2004:23) note that the impact of an experience always depends on its personal meaning to individuals and is linked to their pre-existing level of emotional sensitivity.
It is therefore helpful to consider the various phases of trauma in order to gain an understanding of traumatic stress.

Pre-existing factors are present prior to a traumatic event actually taking place. These factors influence an individual's future ability to cope with traumatic events. They include, age, gender, life circumstances, genes and brain structure, amongst others.

During a traumatic event, an individual experiences a number of various reactions and sensations. These include physical, emotional and mental reactions which are frequently accompanied by an overwhelming sense of fear and helplessness and an autonomic response to either freeze, flight or fight.

The period that immediately follows a traumatic event is known as the impact phase. This stage is confusing for the victim as their psychological, emotional, physiological and cognitive responses are powerful and seemingly contradictory. At times, the victim may also experience disassociation. Cohen (2011:409) puts it as follows: 'Dissociation is similar to a trance state, which is an altered state of consciousness in which awareness of the surrounding world is changed.' Spiritually, the victim's belief in the protection and even the very existence of God is challenged. Questions regarding the purpose and meaning of the event are frequently asked of God. Herman (1997:51) notes that traumatic events can therefore violate a victim's faith.

\section{Post-traumatic stress disorder}

Should the traumatised person not overcome the normal reactions to a traumatic event, then he or she is predisposed to developing post-traumatic stress disorder (PTSD). Antoinette Pienaar (2008) reported that Allers, a psychiatrist and former president of the South African Society of Psychiatry had stated that, up to six million South Africans may suffer from post-traumatic stress disorder. As stated previously, spousal rape victims are likely to develop PTSD due to the severity of their traumatic event. Kinchin (2007:21) concurs with this belief and notes that rape victims are $50 \%$ more likely to suffer from post-traumatic stress disorder. According to Jaycox, Zoellner and Foa (2002:892), most rape victims display posttraumatic stress disorder symptoms immediately subsequent to a rape and for some, these symptoms may persist for years, with devastating consequences.

There are three main reaction clusters in PTSD (see American Psychiatric Association 1994). Firstly, there are intrusive symptoms which in essence, are unsolicited thoughts. Secondly, there is avoidance of stimuli that remind the traumatised person of the traumatic situation and a numbing of general responsiveness that was not present prior to the traumatic event having occurred. Thirdly, there is hyperarousal, which causes the traumatised person to constantly feel alert to any stimulus and on guard. 


\section{Rape trauma syndrome}

In 1972 Holmstrom and Burgess (1987) observed a pattern of reactions in individuals who had been raped and labelled these as 'Rape Trauma Syndrome'. Leslie (2003:28) points out that this syndrome was the first comprehensive model that was formulated to understand the trauma of rape from the victim's perspective.

Rape trauma syndrome is a useful concept for a number of considerations. Firstly, the term rape trauma syndrome considers rape from the victim's point of view. Secondly, rape trauma syndrome includes a cluster of emotional and psychological responses to the extreme stress experienced by the victim due to a sexual assault, both immediately after the rape and in the months and years that follow. Thirdly, rape trauma syndrome is not an illness or a personality disorder. Leslie (2003:38) puts it as follows: 'It is a normal response to an abnormally traumatic event.'

The diagnostic classification of post-traumatic stress disorder was specifically designed to be used as a diagnostic tool with soldiers in mind. It may therefore be inadequate to fully comprehend the experiences of rape victims and the aftermath of rape. Nevertheless, the precepts of post-traumatic stress disorder are important for pastoral counsellors to understand. Much of what has been written on rape has been written from a post-traumatic stress disorder perspective.

\section{The pastoral counsellor and psychology}

Psychotherapy has become an integral part of today's society. Tertiary institutions have also recently begun to offer qualifications in therapy from a Christian perspective. Many of these centres and institutions promote a psychotherapeutic method.

There are those in the church who are also critical of psychology (see Adams 1974; Bobgan \& Bobgan 1996; Almy 2000). Bulkley (1993:24) on the other hand argues that churches and pastors are unable to adequately and appropriately address the 'deepest hurts of modern man' without the use of secular psychology techniques.

Another approach available for pastoral counsellors is to utilise an integrative approach, that recognises the value of psychology and integrates its concepts into pastoral counselling (see Crabb 1977; Collins 1988). When adopting this approach however, the pastoral counsellor needs to ensure that the useful input of psychology 'in no way contradicts the revelation of Christ in His Word' (Crabb 1977:40).

Cognitive behavioural therapy (CBT) is widely recognised as the most effective psychologically therapeutic method to treat victims of spousal rape who are suffering from post-traumatic stress (see Cooper 2008:47). CBT is a psychotherapeutic approach developed from Ellis's Rational Emotive Therapy in the 1950s (see Nevid 2009:569). The basic theoretical rationale behind CBT is that individuals' emotions and behaviour are largely determined by the way in which they perceive their world. Beliefs, worldviews and schemas therefore have a great influence on a person's interaction with his or her world. Should these perceptions become distorted, dysfunctional behaviour and emotions could result. This would consequently negatively affect an individual's relationships, functioning and behaviour.

According to Conservative Evangelicalism, scripture points out that right behaviour results from correct core beliefs. It is therefore necessary for believers to challenge their own thoughts, beliefs and presuppositions. The scriptures provide the means by which to understand the truth of who people are. They should then conform their thinking to scripture and act out that reality. This means that believers do not subjectively develop beliefs that suit them, but rather place themselves under the authority of scriptural principles through which objective truth is to be found. The standard by which the believer is to assess faulty behaviour, emotions, attitudes, worldviews and cognition is therefore found in scripture. It is for this reason that some scriptural principles are considered to be compatible with the therapeutic objectives of CBT. Tan (2011:274), for instance, is of the opinion that CBT has the potential to be positively integrated into Christian models of counselling. Whilst there may be synergy between CBT and pastoral counselling, there are also however distinct differences. From a Conservative Evangelical perspective, the idea of 'thinking towards renewal' is invalid. Rather, believers are renewed by 'faith' and their minds are to be transformed 'by truth which is beyond us' (2 Cor 5:17). The apostle Paul, in 2 Corinthians $5: 17$, adds that the past is over and the focus should therefore be on the present. Scrivener (2007) sets out the parameters for the pastoral usage of CBT and emphasises that believers should be encouraged to explore the biblical passages that guide their beliefs and thinking, rather than to develop relationships with therapists in the fields of psychology and psychiatry. Scriptural passages originated with God, whereas therapists have merely developed humanist techniques. Any CBT techniques used should therefore be applied with the Bible in mind. Any pastoral counselling offered should also be undertaken with an emphasis on scripture readings, prayer, spiritual rituals and the church community.

\section{The pastoral counsellor and spirituality}

A woman who has been raped by her husband is not only affected physically, emotionally, psychologically and cognitively, but also spiritually. Issues of trust, belief in self and God, and questions regarding the purpose and meaning of life are evoked at such times. These aspects are not always adequately addressed by health care practitioners, who are required by their profession to refrain from discussing religious matters and who may have differencing spiritual beliefs and frames of reference to those of their clients. 
Even pastoral counsellors do not always give the necessary attention to the spirituality of those who are traumatised. This is however a vital aspect, in terms of the manner in which pastoral counsellors should attend to spousal rape victims who are also believers and whose faith has more often than not been negatively affected by their traumatic experiences.

According to Fuller (2001:9), spirituality exists wherever humankind struggles with the issue of how their lives fit into the greater scheme of things. Spirituality is then not merely an addendum to life, but touches the core of humanity. Perrin (2007:22) confirms this with his statement that 'spirituality stands at the junction where the deepest concerns of humanity, and the belief in transcendental values, come together in the movement toward ultimate fulfilment in life.'

For the Conservative Evangelical, spirituality without the belief in and use of the Bible is unthinkable. Carson (1994) confirms that:

if spirituality becomes an end in itself, detached from the core and largely without Biblical or theological norms to define it and anchor it in the objective gospel, then pursuit of spirituality, however nebulously defined, will degenerate into nothing more than the pursuit of certain kinds of experience. (p. 391)

From the perspective of Conservative Evangelicalism, it is clear that the Bible influences every aspect of life, belief, attitude and behaviour. This implies that the use of scripture in the care and counselling of believers plays a pivotal role (see McMinn \& Campbell 2007:207). Batholomew (2006:135) regrets that this is not always the case and gives two reasons: firstly, pastoral counselling has been strongly influenced by psychotherapy and this has resulted in scripture being marginalised and often considered to be irrelevant. Secondly, it is often difficult to relate the results of historical-critical readings to pastoral care. Benner (2003:58) cautions however that 'the Bible's use in counseling must be disciplined and selective, and particular care must be taken to ensure that it is never employed in a mechanical or impersonal manner.'

\section{The pastoral counsellor and doctrine}

Doctrine has been criticised as a vehicle for the further restriction and disempowerment of women. It is accused of adding to the plight of women trapped in abusive marriages. Doctrine may well be applied to such situations in a distorted way, however an adequate understanding of doctrine, as it has been developed through close scrutiny of scripture, can be useful and comforting to such women.

An important doctrine that is necessary to expound with victims of spousal rape is that of the image of God. It indicates the intrinsic worth, value and dignity of humankind. This means that victims (and even perpetrators) are to be treated with respect and care. According to Schonborn (2011:42), humanity has meaning only when related to the image of God. Erickson (1985) highlights an important principle:

Because all are created in the image of God, nothing should be done that would encroach upon another's legitimate exercise of dominion, depriving someone of freedom through illegal means, manipulation, or intimidation is improper. (p. 536)
A second doctrine that would aid the spousal rape victim is that of sin and forgiveness. The victim will at some or other time be faced with this important decision regarding the perpetrator.

At times, spousal rape victims experience a sense of condemnation (Flowers 2006:45; Glanville 2012:80). The task of the pastoral counsellor is to work through this particular schema and bring inappropriate beliefs to the fore. Sin not only relates to intentional wrongful behaviour, but individuals may also be sinned against as a result of the wrongful behaviour of others. This can and does have devastating consequences for the overall well-being of the victim of spousal rape. Forgiveness is not without its problems. Poling (2003:192) warns of the dangers of pastors urging premature forgiveness and believes that forgiveness can be used as a weapon against the victim. Nevertheless, a number of therapists and theologians believe that forgiveness is an important part of the healing process (see Fortune 2002; Poling 2003; Tracy 2005). The purpose of forgiveness is for the victim to be released from negative emotions and their consequences and to develop opportunities for healthy relationships and improved spiritual, psychological and physical health.

\section{The pastoral counsellor and patriarchy}

The social system of patriarchy is generally considered to be the root of all oppression and the prime causal factor of abuse against women (see Poling 1991:29; Berlowe 2011:313). Rich (1986) defines patriarchy as:

the power of the fathers: a familial social, ideological, political system in which men by force, direct pressure, or through ritual, tradition, law, and language, customs, etiquette, education, and the division of labor, determine what part women shall or shall not play. (p. 57)

On the other side of the spectrum, Dutton (1994:125ff.) notes that there is no direct causal relationship between patriarchy and woman abuse. According to him, patriarchy does not provoke violence against women in an explicit fashion. Rather, it is used as a tool by 'personality-disordered men' to justify their abuse of women (Dutton 1996:142).

It is possible that patriarchy contributes to the problem of spousal rape however there exist a number of additional contributing factors that should be taken into consideration. Patriarchy cannot be deemed to be a universal constant.

In biblical times, patriarchy was the commonly accepted social system. The biblical view of patriarchy is for the father to be the head of the home and responsible for the conduct of his family. Not only was this the social system of the day, but throughout the Bible there are instructions as to how this system is to operate. It is for this reason that Conservative Evangelicals hold to the system of biblical patriarchy. According to Moore (2006:576), Conservative Evangelicals who hold to this view of patriarchy should speak out against 
spousal abuse, because studies demonstrate that positive patriarchal gender roles assist in the protection against spousal and child abuse. Kostenberger (2008) adds that:

it is necessary to elaborate on the difference between patriarchy and what may be called patricentrism, between harsh male dominance on the one hand and loving, caring leadership on the other. (p. 40, [emphasis added])

Due to the negative connotations of patriarchy, some Conservative Evangelicals hold to a system called 'complementarianism'. Kostenberger (2008:180) defines complementarianism as 'a non-feminist evangelical approach, [which] contends that male-female equality in personhood and value must be placed within the larger framework of male-female distinctions in role.' The term therefore implies difference. Conservative Evangelicals recognise this difference between husband and wife to be not only in terms of gender, but also in terms of the distinct roles of each gender. For the complementarian, the Bible promotes gender equality in worth and dignity, whilst preserving distinct gender roles. Whilst these roles are different in content and nature, they are equal in value. Complementarianism is concerned with more than solely gender roles. The attitude and the manner in which these roles are carried out are of paramount importance:

- Firstly, headship of the male has nothing to do with superiority or privilege. It is rather based on equality.

- Secondly, complementarianism is grounded in love. Complementarians liken the means of headship of the male over the female to the sacrificial love Christ has for his church. Furthermore, husbands are to treat their wives in the same caring manner in which they care for their own bodies (Eph 5:28).

- Thirdly, complementarians believe that male authority is delegated by God (see James 2010:154). In other words, males are fully accountable to God for the way in which they carry out this task and apply their delegated authority.

- Fourthly, husbands are instructed to protect their wives - even to the point of death (Eggerichs 2004:205). This extends to not only physical, but also emotional, psychological, social, sexual and spiritual protection. This protection is not meant to be restrictive, but should rather include the liberty of personal, physical, social, emotional and intellectual growth and stimulation.

\section{The pastoral counsellors and a counselling model}

This article deals with the traumatic experiences of the spousal rape victim and a counselling model to assist her in her time of crisis. The interaction with the perpetrator, as important a factor as that is for the recovery of the victim as well as the habitation of the perpetrator, is outside of the scope of this article.

Crisis intervention is the stage directly after a traumatic event has occurred. For a spousal rape victim, this could be an approach to a pastoral counsellor or anyone else for assistance. During this initial phase, psychological care revolves around safety, acceptance, believing her story, information and containment. This is not the time for 'counselling' whether it is psychological or biblical in nature.

The pastoral counsellor's role is to stand in the gap and assist the woman practically, both at the hospital and/or police station, as well as with any concerns she may have for her children. A safe place should be provided for her and her children in the days to follow and she should be referred to the appropriate social and legal services. The pastoral counsellor should know the rights of the victim as set out in the Service charter for victims of crime in South Africa (South Africa Government 2010) and ensure that these rights are protected. The pastoral counsellor should be aware of how to deal with a spousal rape victim even prior to police and medical involvement. They should be familiar with the medical and legal processes and resources in order to assist the victim to make an informed decision. The role of the pastoral counsellor at this time is to support the victim and not to insist on a particular plan of action. The victim at this time needs support and information as to how to proceed. The pastoral counsellor should at the least have a basic knowledge of psychological theory and trauma reactions. He or she should know which local resources are available to victims of spousal rape. Further, the pastoral counsellor should be careful that his other religious affiliation or convictions do not become the cause of further distress to the victim. There is no short-term approach to healing for the spousal rape victim. The pastoral counsellor should therefore be prepared to be involved with the victim on a long-term basis. Cooper-White (2012) puts it as follows:

We too are called to be witnesses, martyrs, in the sense of not shrinking from one another's cries of pain, but entering into the costly but godly vocation of being-with. (p. 30)

The second phase of counsel is for the pastoral counsellor to engage with the schema of the spousal rape victim. This is to assist the victim to identify negative patterns of thinking, feeling and behaving, and to then replace them with healthier biblical alternatives. McMinn and Campbell (2007:247) explain that if a schema contains excessively negative beliefs and assumptions, an individual could then develop a resulting inaccurate view of the self and could misunderstand social cues in an unhealthy manner. This can have serious emotional and interpersonal consequences. A number of believers have inaccurate schemas regarding the Christian faith. Many of these erroneous schemas are derived from the believer's own negative experiences and assumptions and/or poor theological teaching. The spousal rape victim could struggle even more with such schemas due to her trauma. The pastoral counsellor should address this issue, irrespective of how long it takes. In the introduction to his book, Radical grace, Ellens (2007:xviii) contends that the quality or state of a people's health is definitively affected by their concept of God and actual ontological relationship with God, as well as their perceived relationship with God.

The third phase of counsel involves relationship development. Humankind is comprised of relational beings 
who interact with others, self and God. Spousal rape victims frequently experience relationship difficulties (Flowers 2006:45). These problematic relationships not only involve the abusive husband, but also other individuals with whom the spousal rape victim is involved (such as children, parents and friends) and individuals with whom they may interact in the future. One of the issues the pastoral counsellor may have to address is whether or not spousal rape is grounds for divorce. The key factor the pastoral counsellor needs to take into consideration in this instance, is the understanding of the Greek word 'porneia' which means more than 'adultery', it also encompasses sexual deviance (see Stassen \& Gushee 2006:285). The spousal rape victim experiences intrapsychic conflict, which may lead to other complex and problematic issues such as low self-esteem, emotional disorders (such as depression and anxiety), personality disorders and behavioural disorders (see Bender 1997:306). McMinn and Campbell (2007:317) note that relational healing often requires one to three years of therapy (and sometimes longer). This illustrates the severity of spousal rape to the victim and the approximate duration of appropriate pastoral counselling intervention.

Christianity is a relationally-based faith. It is therefore important to explore the healing value of faith with regard to the relational issues of spousal rape. Solid relationships should be forged between the victim of spousal rape and members of the community and church. This requires pastoral counsellors to initiate support groups which will increase opportunities for spousal rape victims to form new and supportive relationships. Members of the church and community should accept the spousal rape victim in her own right, without necessarily having to be informed of the details of her traumatic experiences.

The fourth phase of counsel is for the pastoral counsellor to facilitate post-traumatic growth. Studies in post-traumatic growth have indicated that some people who have experienced traumatic incidents can in fact also demonstrate psychological, social and spiritual growth as they struggle with the aftermath of the traumatic event (see Linley \& Joseph 2004; Magyar-Moe 2009). At this time, the pastoral counsellor is to apply scriptural truth and the resources of faith, to guide the transformation of spousal rape victim, to spousal rape victor, through the work and person of Jesus Christ. The scriptures give insight into the growth that is possible as a result and in spite of suffering. According to Marshall (2008:3), suffering can be positive when sufferers perceive themselves as having gained something valuable, both subsequent to and as a result of their suffering. The apostle Paul, who was no stranger to suffering, expressed his struggles and triumphs, as well as their positive outcomes. He also taught about how to deal with suffering and the positive spiritual growth that is able to come from it.

Scripture indicates that suffering results in a number of gains for the spousal rape victim:
- Firstly, there is sanctification. Stott (2006:308, 309) develops the idea that God uses suffering as a means of sanctifying believers.

- Secondly, suffering promotes the refining of faith. Scripture makes use of the metaphor of a refiner's fire, through which God refines the faith of God's people.

- Thirdly, suffering increases humility. Crosby (2004:40) understands humility in the Bible, as abandoning one's own sense of control and anxiety and having a fully confident faith in God.

- Fourthly, dependence on God is encouraged. Heitritter and Vought (2006:126) state, 'accepting one's powerlessness lays a foundation for restorative dependence on God, and the movement toward healing begins with restoration of personal worth.'

- Fifthly, suffering encourages perseverance. Suffering is linked to perseverance in a number of scriptural passages (Rm 5:3-4, Ja 1:2-4).

- Sixthly, the spousal rape victim is able to develop the ability to comfort others. Believers are often able to minister to others, as a direct result of their own suffering (2 Cor 1:3-5).

- Seventhly, suffering is linked to joy. A number of scriptural passages link suffering to joy (1 Pt 4:13-19; Ac 5:41-42; Mt 5:11-14).

- Eighthly, hope is a possible outcome of suffering. The scriptural concept of hope is that it is grounded in future certainty. Moltmann (2002:7) elaborates, 'Christian hope finds in Christ not only a consolation in suffering, but also the protest of the divine promise against suffering.'

- Ninthly, wisdom is gained from suffering. In order to experience happiness, wisdom is required and in order to acquire wisdom, suffering is necessary (Kreeft \& Tacelli 2010:54).

- Tenthly, suffering broadens ministry. This expectation is expressed by different people in the scriptures, Jesus (Mt 10:22), Paul (Ac 14:21-22; Phlp 1:29-30; 2 Tm 3:12) and Peter (1 Pt 4:12-13).

It is important to note that suffering does not automatically result in a positive outcome for the believer. It has the ability to either destroy, or develop the believer's faith and it is for this reason that the pastoral counsellor should gently guide, direct, encourage and at times, teach the truths of scripture to the spousal rape victim.

Victim growth or development as a direct result of suffering does not condone or excuse the actions of the perpetrator of spousal rape. Neither does it suggest that the spousal rape victim should remain in her abusive situation and helplessly endure suffering as 'God's will for her life.' There is no doubt that the victim should seek safety and a means of terminating the abuse. The perpetrator cannot be permitted to continually sin, in order for the victim's sanctification to develop. God requires justice to take its course and has set social justice structures in place to achieve this end. The justice system frequently fails victims of rape and more especially, spousal rape (see Chandra 2004:131). The spousal rape victim can nevertheless take comfort in the knowledge that nothing 
escapes God, who will ensure that justice is ultimately carried out to its fullest extent (see Aikman 2006:247).

The scriptures can assist the pastoral counsellor in guiding the spousal rape victim to the reality that she is able to be emancipated from the label of 'victim' and to live a life that is expressed in joy, contentment, hope, fulfilment, growth, empowerment and purpose, through the enabling power of God. Romans (8:37) states that believers are 'more than conquerors.' This statement is made in the context of 'our present sufferings' ( $\mathrm{Rm} \mathrm{8:18)}$ and it is therefore during suffering, that the presence of God is assured (Rm 8:38, 39). No accusation can be brought against the chosen ( $\mathrm{Rm} 8: 33)$

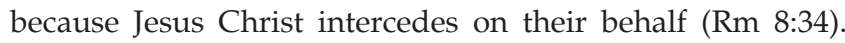
This is the message for the spousal rape victim who is a believer. It does not imply a form of Christianity that lives a triumphant life, with no regard to the problematic issues of doubt and discouragement. Rather, being 'more than conquerors' means that believers have the full assurance of God's presence, involvement and empowerment in the midst of their struggles and problems. The role of the pastoral counsellor is therefore to disciple this victorious victim to a life that glories God.

\section{The pastoral counsellor and the church}

One of the resources available to the pastoral counsellor is his or her access to the local church. The local church has an important role to play in the well-being of the spousal rape victim. Whilst the church would not necessarily be aware of particular incidents of spousal rape, their support to and acceptance of those hurting ought to be evident. Secondly, members of the local church need to be educated concerning rape in general, spousal rape and domestic violence. Pastoral counsellors ought to develop educational and informative programmes to disperse this information. They should break the silence on rape. Kowalski (1988:202) believes that church members who have experienced spousal rape are wary of asking for pastoral counselling if they have not been explicitly invited to do so. Pastoral counsellors need to seek ways in which to not only support the victims, but to also address the perpetrators of rape by various means, that is, through church discipline, counsel, support groups and referral to appropriate resources within and/or outside of the church.

Delaphane and Delaphane (2004:157) point out that marital rape is still not receiving sufficient attention. It is therefore necessary for pastoral counsellors to take steps to address this issue within their local churches.

\section{The pastoral counsellor and training}

It is assumed that the pastoral counsellor received theological training at an accredited institution. It is also assumed that the pastoral counsellor has the necessary gifts of the Holy Spirit (encouragement, mercy, wisdom, etc.) in order to perform the work of pastoral counselling (see Jones 2006:166). In addition, it is assumed that the pastoral counsellor is practicing biblical truths and spiritual disciplines. Beyond these requirements, the pastoral counsellor also needs to understand humankind, their desires, struggles, beliefs, et cetera. The pastoral counsellor is also expected to understand the natural and/or problematic reactions and responses precipitated by crises, difficulties and in the case of this article, traumatic events, such as spousal rape. This may require the additional reading of articles and books, attending seminars, discussion groups and even further institutionalised training.

The role of any Christian leader is to develop and mentor other believers. This is also true for pastoral counsellors, as they seek opportunities in which to train others by means of education, mentorship, supervision and even observation.

The pastoral counsellor needs to grow in the conviction that pastoral counselling is the birthright of the Christian faith and not the sole responsibility of secular mental health professionals. This will encourage the pastoral counsellor to invest in the development of skills, education, spiritual maturity and a deep love for people, before being tempted to prematurely refer a hurting person to someone outside of the Christian faith (see Lambert 2012:22).

\section{The pastoral counsellor and self-care}

Health professionals who work with traumatised individuals are at high risk of experiencing negative emotional and physical reactions (Collins \& Long 2003). These reactions are possibly even more applicable to pastoral counsellors, who do not necessarily have the 'professional distance' that is a prerequisite for other health care professionals. There are however both positive and negative consequences to working with trauma victims.

One such risk is that of burnout:

- The pastoral counsellor is already exposed to many work and family stressors (including a possible spiritual attack) and working with traumatised victims merely exacerbates the situation and can lead to burnout. This causes the pastoral counsellor to be less effective in his or her counselling. One of the symptoms of burnout is that of emotional exhaustion. This causes the pastoral counsellor to develop a decreased ability to provide appropriate care and intervention to the spousal rape victim.

- A second symptom of burnout is that of depersonalisation. According to Simeon and Abugel (2006:13), 'detachment or estrangement from oneself, coupled with an awareness of this detachment, is the essence of depersonalisation'. The spousal rape victim could therefore experience a sense of distancing and cynicism from the pastoral counsellor. The worst case scenario in this instance, is that the pastoral counsellor could behave in a way that is dehumanising and objectifying to the spousal rape victim and treat her like a 'case' instead of a person.

- A third symptom of burnout is that of a sense of decreased personal accomplishment. The pastoral counsellor experiences a feeling of futility and concludes that he or she is failing to make a valuable difference to the victim. 
The pastoral counsellors perceive all his or her efforts as being worthless and they feel helpless to assist the victim or to change the evils of society.

The pastoral counsellor is also at risk of vicarious traumatisation. Vicarious traumatisation occurs when the pastoral counsellor over identifies with a spousal rape victim and her traumatic incidents, to the point that the pastoral counsellor experiences a post-traumatic stress reaction. Larsen and Stamm (2008:279) explain it as follows: 'Vicarious traumatization transformations include lasting and pervasive schema changes about the self and one's world.' The symptoms of vicarious traumatisation are similar to those of traumatic reaction symptoms experienced by the spousal rape victim. These symptoms are exacerbated if the pastoral counsellor experiences counter-transference or if the pastoral counsellor reflects on how such a traumatic event could affect himself or herself or his or her family. Vicarious traumatisation causes the pastoral counsellor to struggle with his or her place of reference, worldview and even his or her own spirituality. Many pastoral counsellors may have themselves experienced a traumatic event and this could result being re-traumatised if triggered by the victim's story.

Compassion fatigue is another risk that faces the pastoral counsellor. Compassion fatigue involves the reduced capacity for empathic engagement. Weaver et al. (2004:154) explain compassion fatigue as the emotional cost of exposure to working with those who have been traumatised. There are a number of reasons for the pastoral counsellor to be susceptible to compassion fatigue. Empathy is recognised as an essential characteristic when counselling traumatised individuals (Figley 1995:15). The pastoral counsellor generally considers his or her work to be more of a calling than a vocation. This could possibly result in them being even more empathic than health care practitioners. Pastoral counsellors are also required to not only display empathy, but also compassion and 'to bear the load alongside' the person suffering (Scalise 2011:419).

There are however also many positive outcomes resulting from the pastoral counselling of traumatised individuals. Compassion satisfaction is a term used to describe the sense of fulfilment and satisfaction that the counsellor derives from performing his or her work to the best of their ability (Collins \& Long 2003). The pastoral counsellor feels that his or her work is meaningful and makes a difference to individuals and the world. According to Larsen and Stamm (2008:283), compassion satisfaction 'may be the most potent force in motivating continued work even in the presence of the negative "costs" of caring.' Further, there is the possibility that the pastoral counsellor may experience post-traumatic growth, in much the same manner as the spousal rape victim does.

\section{Conclusion}

There is much criticism regarding the effectiveness of pastoral counselling in assisting the well-being of spousal rape victims however this needs not be the case. The pastoral counsellor is well placed to address the holistic needs of the victim. The process of assisting the spousal rape victim to transform from victim to victor is an intense, prolonged and emotionally demanding one. This requires time, commitment and sacrifice on the part of the pastoral counsellor. The outcome is however well worth it. Any pastoral counsellor who is up for this challenge should be aware of what the helping process will entail and be prepared to be patient, consistent, reliable, self-aware, tenacious and committed.

A pastoral counsellor who is reliant upon the guidance, wisdom and power of the Holy Spirit and uses his or her spiritual gifting, understanding, compassion, theoretical and theological knowledge of the tenets of spousal rape and competent counselling skills, is adequately equipped to assist a victim of spousal rape.

\section{Acknowledgements Competing interests}

The authors declare that they have no financial or personal relationship(s) that may have inappropriately influenced them in writing this article.

\section{Authors' contributions}

This article represents a reworked version of aspects from the PhD dissertation of J.A.G. (University of Pretoria), with Y.D. (University of Pretoria) as supervisor.

\section{References}

Adams, J.E., 1974, The big umbrella, Baker Books, Grand Rapids.

Aikman, D., 2006, Jesus in Beijing, Regnery, Washington.

Almy, G.L., 2000, How Christian is Christian counselling?, Crossway Books, Wheaton.

American Psychiatric Association, 1994, Diagnostic and Statistical Manual of Mental Disorders (DSM-IV), 4th edn., American Psychiatric Association, Washington.

Andersen, J., 2007, Woman submit! Christian and domestic violence, One Way Cafe Press, Auburndale.

Astbury, J. 2006, 'Services for victim/survivors of sexual assault. Identifying needs, interventions and provision of services in Australia', Australian Centre for the Study of Sexual Assault Issues 6, 1-28.

Bachar, K.J. \& Koss, M.P., 2002, s.v. 'Rape', in J. Worell (ed.), Encyclopedia of women and gender, two-volume set: Sex similarities and differences and the impact of society on gender, Academic Press, San Diego, pp. 893-904.

Bartholomew, C., 2006, 'In front of the text; the quest of hermeneutics', in P. Ballard \& S.R. Holmes (eds.), The Bible in pastoral practice, pp. 135-153, Eerdmans Publishers, Grand Rapids.

Bender S.J., 1997, Teaching health science: elementary and middle school, Jones \& Bartlett, Boston

Benner, D.G., 2003, Strategic pastoral counseling: A short-term structured model, Baker Books, Grand Rapids.

Bergen, R.K., 1996, Wife rape, SAGE Publications, Thousand Oaks.

Bergen, R.K., 2006, 'Marital rape: New research and directions', in VAWNet, viewed 30 April 2013 from http://vawnet.org/assoc files_vawnet/ar_maritalraperevised. pdf

Berlowe, B., 2011, The compassionate rebel revolution: ordinary people changing the world, Mill City Press, Minneapolis.

Bobgan, M. \& Bobgan, D., 1996, Psychoheresy: The psychological seduction of Christianity, Eastgate Publishers, Santa Barabra.

Bulkley, E., 1993, Why Christians can't trust psychology, Harvest House Publishers, Eugene.

Burgess-Jackson, K., 1996, Rape: A philosophical investigation, Dartmouth Publishing Company, Hants.

Carson, D.A., 1994, 'When is spirituality spiritual? Reflections on some problems of definition', Journal of Evangelical Theological Society 37(3), 381-394. 
Centre for the study of violence \& reconciliation 2001, Reviewing the link between HIV/AIDS and the violence against women, Creative Communication Alliance, Johannesburg.

Chandra, R., 2004, Liberation and social articulation of Dalits, Isha, Dehli.

Cohen, L.J., 2011, The handy psychology answer book, Visible Ink Press, Canton.

Collins, G., 1988, Christian counseling: A comprehensive guide, Word Publishing, Dallas.

Collins, S. \& Long, A., 2003, 'Working with the psychological effects of trauma: consequences for mental healthcare workers a literature review', Journal of Psychiatric and Mental Health Nursing 10(4), 417-424. http://dx.doi.org/10.1046/ j.1365-2850.2003.00620.x, PMid:12887633

Cooper, M., 2008, Essential research findings in counselling and psychotherapy: The facts are friendly, SAGE Publications, Thousand Oaks.

Cooper-White, P., 2012, 'Suffering', in B.J. Miller-McLemore (ed.), The Wiley-Blackwell companion to practical theology, pp. 23-31, Wiley-Blackwell, Malden.

Crabb, L., 1977, Effective Biblical counseling: A model for helping caring Christians become capable counselors, Zondervan Publishing House, Grand Rapids.

Crosby, S., 2004, Silent killers of faith: Overcoming legalism and performance-based religion, Destiny House, Shippensburg.

Delaplane, D. \& Delaplane, A., 2004, Victims of child abuse, domestic violence, elderly abuse, rape, robbery, assault, and violent death: A manual for clergy and congregations, Diane Publishing Company, Darby.

Development Research Africa and CSIR Defence, Peace, Safety and Security Unit, 2008, Consolidated Report on the Nature and Prevalence of Domestic Violence in South Africa, viewed 06 June 2012, from http://www.cindi.org.za/files/eNews/ enews13/Consolidated_Report_Domestic_Violence_South\%20Africa.pdf

Dutton, D.G., 1994, 'Patriarchy and wife assault: The ecological fallacy', Violence and Victims $9(2), 125-140$

Dutton, D.G., 1996, 'Patriarchy and wife assault: The ecological fallacy', in L.K. Hamberger \& C.M. Renzetti (eds.), Domestic partner abuse, pp. 125-152, Springer Hamberger \& C.M. Renzetti (eds.
Publishing Company, Broadway.

Easteal, P.W., 1998, Balancing the scales: rape, law reform, and Australian culture, Federation Press, Leichhardt.

Eggerichs, E., 2004, Love \& respect: The love she most desires, the respect he desperately needs, Thomas Nelson, Nashville.

Ellens, H.J., 2007, Radical grace how belief in a benevolent God benefits our health, Praeger Publishers, Westport. PMid:17967933

Ellis, L., 1989, Theories of rape: Inquiries into the causes of sexual aggression, Hemisphere Publishing, New York.

Erickson, M.J., 1985, Christian theology, Baker Books, Grand Rapids.

Emmerson, G.I., 1995, 'Women in acient Israel', in R.E. Clements (ed.), The World of Ancient Israel, pp. 371-394, Cambridge University Press, Cambridge.

Figley, C.R., 1995, Compassion fatigue: Coping with secondary traumatic stress disorder in those who treat the traumatized, Brunner-Routledge, New York.

Flowers, R.B., 2006, Sex crimes: perpetrators, predators, prostitutes, and victims, Charles C. Thomas, Springfield.

Fortune, M., 2002, 'Introduction', in M.M. Fortune \& J.L. Marshall (eds.), Forgiveness and abuse: Jewish and Christian reflections, pp. 1-6, Haworth Pastoral Press, Binghamton.

Fuller, R.C., 2001, Spiritual, but not religious: Understanding unchurched America, Oxford University Press, New York. http://dx.doi.org/10.1093/0195146808.001.0001

Gelles, R.J., 1997, Intimate violence in families, SAGE Publications, Thousand Oaks. PMCid:1184516

Glanville, J.A., 2012, 'Spousal rape: An integrative approach for pastoral counselling', PhD thesis, Department of Theology, University of Pretoria.

Goldingay, J., 2009, Old Testament theology, vol. 3: Israel's life, Intervasity Press, Downers Grove.

Greenberg, J.S., Bruess, C.E. \& Conklin, S.C., 2010, Exploring the dimensions of human sexuality, Jones \& Bartlett, Sudburg.

Heitritter, L. \& Vought, J., 2006, Helping victims of sexual abuse, Bethany House, Minneapolis.

Herman, J., 1997, Trauma and recovery, Basic Books, New York.

Holmstrom, L.L. \& Burgess, A.W., The victim of rape: instituional reactions, Transaction Books, New Brunswick.

James, C.C., 2010, Half the church: Recapturing God's global vision for women, Zondervan, Grand Rapids.

Jaycox, L.H., Zoellner, L. \& Foa, E.B., 2002, 'Cognitive-Behavior Therapy for PTSD in rape survivors', Journal of Clinical Psychology 58(8), 891-906. http://dx.doi. org/10.1002/jclp.10065, PMid:12115713

Jones, I.F., 2006, The counsel of heaven on earth: foundations for biblical Christian counselling, Broadman \& Holman Publishers, Nashville.

Kernsmith, P., 2008, 'Sexual coercion and domestic violence', in J. Keeling \& T. Mason (eds.), Domestic violence: A multi professional approach for healthcare practitioners, pp. 54-66, Open University Press, Maidenhead.

Kinchin, D., 2007, A guide to psychological debriefing: Managing emotional decompression and posttraumatic stress disorder, Jessica Kingsley Publishers, London.
Kostenberger, M.E., 2008, Jesus and the feminists: Who do they say that He is? Crossway, Wheaton.

Kowalski, J.A., 1988, 'Developing religious and secular partnerships', in A.L. Horton \& J.A. Williamson (eds.), Abuse and religion, pp. 199-206, Lexington Books, Lexington.

Kreeft, P. \& Tacelli, R.K., 2010, Pocket handbook of Christian apologetics, InterVarsity Press, Downers Grove.

Lambert, H., 2012, The biblical counselling movement after Adams, Crossway, Wheaton.

Larsen, D. \& Stamm, B., 2008, 'Professional quality of life and trauma therapists', in S. Joseph \& P. Linley (eds.), Trauma, recovery and growth: Positive psychological perspectives on posttraumatic stress, pp. 275-294, John Wiley, Hoboken.

Leslie, K.J., 2003, When violence is no stranger, Fortress Press, Minneopolis.

Leoschut, L. \& Burton, P. 2006, 'How rich the rewards? Results of the 2005 National Youth Victimisation Study' in Centre for justice and crime prevention, viewed on 30 April 2013, from http://www.cjcp.org.za/admin/uploads/Final.RichReward.pdf

Linley, A.P. \& Joseph, S., 2004, Positive psychology in practice, John Wiley, Hoboken. http://dx.doi.org/10.1002/9780470939338, PMCid:523340

Magyar-Moe, J., 2009, Therapist's guide to positive psychology interventions, Academic Press, Burlington.

Mahoney, P. \& Williams, L.M., 1998, 'Sexual assault in marriage: Prevalence, consequences, and treatment of wife rape', in J.L. Jasinski \& L.M. Williams (eds.),
Partner violence: a comprehensive review of 20 years of research, pp.113-162, Partner violence: a compreher
SAGE Publications, London.

Mahoney, P. \& Williams, L.M., 2007, 'Sexual assault in marriage: Prevalence, consequences, and treatment of wife rape', viewed 05 June 2012, form http:// consequences, and treatment of wife rape', view
brockbaker.pbworks.com/f/PartnerViolence.pdf

Marshall, C., 2008, 'Suffering toward sanctification', MA thesis Religion, Reformed Theological Seminary.

McGregor, J., 2005, Is it rape? On acquaintance rape and taking women's consent seriously, Ashgate Publishing Limited, Aldershot.

McMinn, M.R., \& Campbell, C.D., 2007, Integrative psychotherapy: Toward a comprehensive Christian approach, InterVarsity Press, Downers Grove.

Moltmann, J., 2002, Theology of hope: On the ground and the implications of a Christian eschatology, SCM Press, London.

Moore, R.D., 2006, 'After patriarchy, what? Why egalitarians are winning the gender debate', Journal of the Evangelical Theological Society 49(3), 569-576.

Nason-Clark, N., 1997, The battered wife: How Christians confront family violence, Westminster John Knox Press, Louisville.

Naylor, N., 2008, 'The politics of definition', in L. Artz \& D. Smythe (eds.), Should we consent? Rape law reform in South Africa, pp. 22-55, Juta \& Co., Cape Town.

Nevid, J.S., 2009, Psychology:Concepts and applications, Houghton Mifflin, Boston.

Perrin, D.B., 2007, Studying Christian spirituality, Routledge, New York.

Pienaar, A., 2008, '25\% have mental problems', News 24, 06 June, viewed 01 May 2013, from http://www.news24.com/SouthAfrica/News/25-have-mental-problems20080605

Plichta, S.B. \& Falik, M., 2001, 'Prevalence of violence and its implications for women's health', Women's Health Issues 11(3), 244-258. http://dx.doi.org/10.1016/S1049 3867(01)00085-8

Poling, J.N., 1991, The abuse of power: A theological problem, Abingdon Press, Nashville.

Poling, J.N., 2003, Understanding male violence: pastoral care issues, Chalice Press, Danvers. PMCid:1284457

Purdy, E.R., 2004, s.v. 'Marital rape', in M.D. Smith (ed.), Encyclopaedia of rape, Greenwood Publishing, Westport, pp. 122-124.

Randall, M. \& Haskell, L., 1995, 'Sexual violence in women's lives' Violence against Women 1(1), 6-31. http://dx.doi.org/10.1177/1077801295001001002 PMid:12346573

Rasool, S., Vermaak, K., Pharaoh, R., Louw, A. \& Stavrou, A., 2003, Violence against women: A national survey, Institute of Security Studies, Pretoria.

Rich, A., 1986, Of woman born, W.W. Norton, New York.

Scalise, E., 2011, 'Compassion and empathy', in T.E. Clinton \& R. Hawkins (eds.), The popular encyclopaedia of Christian counseling, pp. 413-440, Harvest House Publishers, Eugene.

Scholtz, S., 2004, s.v. 'Resistance', in M.D. Smith (ed.), Encyclopaedia of rape, Greenwood Press, Westport, pp. 209-211.

Schonborn, C.C., 2011, Man, the image of God: The creation of man as good news, Ignatius Press, San Francisco.

Scrivener, G., 2007, 'How should Christians think about CBT?', in Christ the Truth, viewed 09 August 2012, from, http://www.christthetruth.org.uk/cbt.htm.

Simeon, D. \& Abugel, J., 2006, Feeling unreal: Depersonalization disorder and the loss of the self, Oxford University Press, New York.

Stassen, G.H. \& Gushee, D.P., 2006, Kingdom ethics: Following Jesus in contemporary context, IVP Academic, Downers Grove.

Stott, J.R.W., 2006, The cross of Christ, InterVarsity Press, Downers Grove.

Smith, A., 1998, 'Born again, free from sin: Sexual violence in evangelical communities', in C.J. Adams \& M.M. Fortune (eds.), Violence against women and children: A Christian theological sourcebook, pp. 339-350, Continuum, New York. 
Smythe, D. \& Waterhouse, S., 2008, 'Policing sexual offences: Policies, practices and potential pitfalls', in L. Artz \& D. Smythe (eds.), Should we consent? Rape law reform in South Africa, pp. 198-223, Juta \& Co., Cape Town.
retential

South Africa Police Services, 2012, Crime Research and Statistics - South African Police Service, viewed 02 November 2012, from, http://www.saps.gov.za/statistics/ reports/crimestats/2012/categories/total_sexual_offences.pdf

South Africa Government, 2007, Criminal Law (Sexual Offences and Related Matters) Amendment Act, 2007, Government Gazette, vol. 510 (3059), 14 Dece 06 June 2012, from, http://www.info.gov.za/view/DownloadFileAction?id=77866

South Africa Government, 2010, Service charter for victims of crime in South Africa viewed 28 March 2013, from, http://www.npa.gov.za/files/Victims\%20charter.pdf

Tan, S.Y., 2011, Counseling and psychotherapy: A Christian perspective, Baker Academics, Grand Rapids.

Tassman, A. \& Mohr, W.K., 2011, Fundamentals of psychiatry, John Wiley, Chichester.

Tjaden, P. \& Thoennes, N., 2000, 'Extent, nature, and consequences of intimate partner violence. Findings from the national violence against women survey', in National criminal justice reference service, viewed 27 March 2013, from http:// www.ncjrs.gov/pdffiles1/nij/181867.pdf
Tracy, S.R., 2005, Mending the soul: Understanding and healing abuse, Zondervan, Grand Rapids.

Van Niekerk, Z., 2006, 'A rape crisis. Cape Town trust counselling skills course: A qualitative evaluation', MA dissertation, Department of Psychology, University of Western Cape.

Vetten, L., 2007, 'Can the new Sexual Offences Bill deliver on its promises?', SA Crime Quarterly (Institute for Security Studies) 22, 21-25.

Weaver, A.J., Flannelly, L.T. \& Preston, J.D., 2004, Counseling survivors of traumatic events: A handbook for those counseling in disaster and crisis, Abingdon Press, Nashville.

Weaver, T.L., Allen, J.A., Hopper, E., Maglione, M.L., McLaughlin, D., McCullough, M.A., Jackson, M.K. \& Brewer, T., 2007, 'Mediators of suicidalideation within a sheltered sample of raped and battered women', Health Care for Women International 28(5), 478-489. http://dx.doi.org/10.1080/07399330701226453, PMid:17469001

West, T.C., 2004, 'Counseling by clergy', in M.D. Smith (ed.), Encyclopaedia of Rape, Greenwood Press, Westport, pp. 42-43.

Wiehe, V.R. \& Richards, A.L., 1995, Intimate betrayal, SAGE Publications, Thousand Oaks. PMid:8551747 